\title{
Role of Competitive Product Advantages to Rise up Marketing Performance
}

\author{
Aris Mardiyono, Gita Sugiyarti* \\ Faculty of Economics and Business, University 17 August 1945 Semarang
}

DOI: $10.36348 /$ sjef.2020.v04i07.001

| Received: 23.06.2020 | Accepted: 01.07.2020 | Published: 08.07.2020

*Corresponding author: Gita Sugiyarti

\section{Abstract}

The main objective of this research is to develop a conceptual model of competitive advantage that can improve marketing performance. The specific targets of this study empirically examine the effects of market orientation, entrepreneurial orientation, competitive advantage on marketing performance. The sampling technique used was purposive sampling, the sample in this study was the leadership of small and medium food businesses of 225 respondents in Indonesia. The sampling technique used was purposive sampling business leaders in Indonesia. After being collected, it is analyzed with SPSS 16 technique. The theoretical findings in this research namely enriching the literature creating competitive advantage can improve marketing performance. While the managerial findings in this study are models for developing small and medium scale food industries in Indonesia.

Keywords: Market orientation, entrepreneurial orientation, competitive advantage and marketing performance.

Copyright @ 2020: This is an open-access article distributed under the terms of the Creative Commons Attribution license which permits unrestricted use, distribution, and reproduction in any medium for non-commercial use (NonCommercial, or CC-BY-NC) provided the original author and source are credited.

\section{INTRODUCTION}

Today's business competition is getting tougher [1], impact on opportunities and threats from companies at home and abroad. Companies must understand what is happening in the market and what consumers want [2]. A change in the business environment results in competition between companies [3], As a result the company always tries to suppress its weaknesses and optimize its strengths. As a result, companies are required to choose and determine the most appropriate strategy in the face of competition.

Strategies in dealing with competition [4] with competitive advantage. The company considers superior value for consumers with an organizational climate in terms of efficiency and effectiveness. Advances in technology have an impact on products that are difficult to distinguish from competitors [5]. To achieve competitive victory, companies must always improve product quality and corporate strategy [6].

Study [7], explain organizational culture in supporting marketing performance using market orientation. Jyoti \& Sharma [8], the most effective and efficient culture in creating superior value behavior for buyers and superior performance for companies is called market orientation. Thus the corporate culture is urgently needed as external basic needs, and desires, market demand in developing business unit strategies.

In order to realize sustainable and competitive economic growth with entrepreneurship which is an independent entrepreneur in the activities of exerting the power of the mind in creating a job to realize noble human beings [6].

Essel, Adams, \& Amankwah [9], explained that entrepreneurs are able to improve business performance through entrepreneurial orientation. Entrepreneur-oriented company leaders always face risks in creating performance, have a responsive attitude to the environment, by looking at market needs, so that they always innovate products / services to adjust changes to create competitive advantage.

This study is motivated by empirical studies in the field, which show inconsistent results [10]. Several studies confirm the existence of a strong positive relationship between entrepreneurial orientation and performance Arief, Thoyib, Sudiro, and Rohman [11], Li, Huang, and Tsai [12], Zainol and Ayadurai [13] and the other did not find a significant relationship between the two constructs [14]. 
Based on the background and research gap, the research problem is: How do you develop strategies to create competitive advantage over products through entrepreneurial orientation in improving marketing performance?

\section{LITERATURE REVIEW AND HYPOTHESIS Market Orientation}

Study Jogaratnam [7], describes the most effective culture in creating superior value for buyers as well as business performance. There are three indicators namely customer orientation, competitor, and interfunctional coordination. The activity of obtaining information on buyers and competitors in the market is the orientation of customers and competitors. While the coordination between functions gets information from business ventures, the ability to find market information is needed as a basis for further steps.

Rantaa, Keränen, \& Aarikka-Stenroosa [15], understanding of customers aims to create superior value for customers on an ongoing basis, covering the needs of customers today and for the future, efforts can be achieved from the process of finding customer information, to understand current and future potential customers.

$\mathrm{Na}$, Kang, \& Jeong [16], explain the orientation of competitors has a strategy in obtaining and sharing information, responding to the actions of competitors, top management [17]. While salespeople are trying to find competitor information, share information with the functions of the organization in each division of research and product development, so that leaders are able to compete with competitor's power with established strategies. Coordination between functions has the purpose of creating superior value for different organizational functions, enhancing communication and exchanges, informing market trends and encouraging the development of trust and independence of functional units, thereby giving rise to an environment of receiving new products according to customer needs [18].

\section{Entrepreneurship Orientation}

Essel et al., [9], explains entrepreneurship as a creative, innovative ability to get opportunity and success. Three indicators namely innovation, taking risks, and proactive nature.

Lorenzon et al., [4], implementing marketing strategies to improve competitive advantage to get responsiveness to customer needs. Measured with indicators of innovation, risk taking, proactivity, and competitive aggressiveness.

Sofana et al., [6], defining entrepreneurial marketing is a proactive activity of reaching and retaining customers for profit. Koh [19], the ability of innovation related to perceptions and new and unique business activities, is very important in entrepreneurship. Several studies and entrepreneurial literature explain that innovation has an impact on the ability of companies. Proactivity is the application's personal instructions. If the emphasis is on proactivity, it will drive high performance [16]. In organizations, if activities are high, they will remain motivated despite many obstacles and challenges. Active and dynamic attitude is the key to success. Risk is an opportunity for uncertainty in decision making. The main function of optimal risk taking.

\section{Competitive Advantage}

Lorenzon et al., [4], industrial environmental competition occurs between companies. Competitive strategy in the functional department activities, will develop general formulas in business. Objectives and policies are needed in achieving company goals. There are two notions of competitive advantage. First the emphasis is on superior resources and expertise. The company has competencies in manufacturing, marketing, innovation as sources in achieving competitive advantage. Both excel in achieving performance. Related to the company's position compared to its competitors. The development and improvement of performance reaches a good competitive position if it has strong capital to continue to compete.

Rachinger et al., [5], explain the benefit strategy of working together to create competitive advantage. This strategy dominates the market. The benefits are created so that consumers buy products based on the desired value, according to the price offered. Purchases occur if the customer considers the price of the product to be in accordance with quality.

Dziallasa \& Blind [20], indicators of product excellence include uniqueness, competitive prices, scarce, difficult to imitate, and difficult to replace. The uniqueness of the product is a product value according to customer tastes. Competitive price is the match between the price of the product with the general price. Difficult to find means that its existence is rare. Difficult to imitate means that it cannot be imitated. Irreplaceable means not having the same substitute.

\section{Marketing Performance}

Sugiyarti \& Ardyan [21], put forward the company's strategy is directed to produce marketing and financial performance. Three indicators namely sales value, sales growth, and market share. Sales growth is very dependent on the number of customers or product units sold. The high value of sales indicates that more products are being sold. Market share is the amount of product contribution to dominate the market of similar products compared to competitors. 


\section{HYPOTHESIS}

\section{Effect of Market Orientation on Competitive Advantage}

Sugiyarti \& Ardyan [21], Performance indicators include financial and non-financial performance. The results of the study explain the mediation market performance towards the relationship between differentiation advantage and financial performance, the higher the degree of customer orientation, the higher the competitive advantage based on innovation and market differentiation. Jogaratnam [7], Companies using market orientation strategies result in the ability of companies to compete. Na et al., [16], shows that market orientation can create competitive advantage. Based on the description above, a hypothesis is proposed:

H1: Market orientation has a significant positive effect on competitive advantage

\section{The effect of entrepreneurial orientation on competitive advantage}

Study [9], explained that there was a significant positive effect on entrepreneurial orientation on the sustainable competitive advantage of MSMEs. The three variables namely entrepreneurial orientation, sustainable competitive advantage, organizational learning affect the performance of MSME businesses.

Research result [16], states market orientation, innovation, entrepreneurial orientation have a significant positive effect on competitive advantage. This is very different from the findings [4]. The difference lies in the application of entrepreneurial orientation elements that have not been carried out at all or as a whole by business managers because of the existence of these businesses, most of which are still traditional. The business manager does not fully understand how to use the stages or process of entrepreneurial orientation, so there is no significant change in differentiation compared to competitors. Based on the above thinking, a hypothesis can be proposed:

$\mathrm{H} 2$ : Entrepreneurial orientation has a positive effect on competitive advantage

\section{Effect of market orientation on Marketing Performance}

Competence in understanding customers is an opportunity that gives customer satisfaction. The success in controlling the market is if the company always puts the orientation of customers and competitors in harmony. The main dimensions are customer orientation and competitor orientation.

Market-oriented companies are determined by their ability to coordinate marketing between functions, respond quickly to changes in the competitive environment and anticipate any changes in the environment. If the company has a high degree of market orientation, product quality, service quality, product innovation and costs are also high [18]. Jogaratnam [4], an organization using market strategies will provide better services. Based on the above thinking, a hypothesis can be proposed:

H3: Market orientation has a positive effect on marketing performance.

\section{The Effect of Entrepreneurial Orientation on Marketing Performance}

The role of improving business performance through an entrepreneurial orientation is stated $[9,16]$. Rachinger et al., [5], put forward the company's competitive strategy in competing more effectively in the process and decision making for new inputs. There are three indicators namely innovative, proactive and risk-taking.

The attitude above will encourage company performance [21], the higher the entrepreneurial spirit, the more the company's ability to market its products. An entrepreneurial person can carry out activities to increase business performance. Based on the description above, then the hypothesis can be presented as follows:

H4: Entrepreneurial orientation has a positive effect on marketing performance.

\section{Effect of competitive advantage on Marketing Performance}

Study Lorenzon et al., [4], explains that there is a significant positive effect on competing strategies with performance. Some indicators are profitability level, sales volume, market share development, and return on investment. Superior value is obtained from managing and utilizing resources and capital and having competitive strength. Based on the above thinking, a hypothesis can be proposed:

H5: Competitive advantage has a positive effect on marketing performance

\section{RESEARCH METHODS \\ Sample and data Collection Procedures}

Data collection by survey, consisting of primary data from small and medium business owners. Research questions consist of market orientation, entrepreneurial orientation, competitive advantage and marketing performance related to quantitative research. Quantitative data uses the Structure Equation model (SEM), version 16.0.

Snyder [22], purposive sampling is a sampling technique based on certain considerations, the sample is chosen based on essential characteristics according to research [23]. The sample in this study is a small industry that has a. Turnover and assets are below 100 
million, according to Law no. 9/1995 max 200 million, b. The number of workers is 5-19 people, c. Capital of less than 25 Million. So that the number of samples taken 225 respondents.
Operationalization of variables

Operationalization of variables in the following research:

Table-1: Operasionalisasi variable

\begin{tabular}{|l|l|l|l|}
\hline Variable & Conceptual & Indicator & Source \\
\hline $\begin{array}{l}\text { Market } \\
\text { Orientation }\end{array}$ & $\begin{array}{l}\text { Is an effective culture in creating } \\
\text { important and superior behavior for } \\
\text { buyers. }\end{array}$ & $\begin{array}{l}\text { Customer orientation } \\
\text { Competitor orientation } \\
\text { Market information }\end{array}$ & (Jogaratnam, 2017) [7], \\
\hline $\begin{array}{l}\text { Entrepreneurial } \\
\text { orientation }\end{array}$ & $\begin{array}{l}\text { Creative, innovative abilities as a } \\
\text { basis and resources get opportunities } \\
\text { for success }\end{array}$ & $\begin{array}{l}\text { Take risks } \\
\text { Flexible } \\
\text { Anticipatory }\end{array}$ & (Essel et al., 2019) [9] \\
$\begin{array}{l}\text { Competitive } \\
\text { advantage }\end{array}$ & $\begin{array}{l}\text { The heart of marketing performance } \\
\text { is to face competition }\end{array}$ & $\begin{array}{l}\text { The uniqueness of the product } \\
\text { Prices can compete } \\
\text { Rare } \\
\text { Not easy to imitate }\end{array}$ & (Lorenzon et al., 2018) [4] \\
\hline $\begin{array}{l}\text { Marketing } \\
\text { performance }\end{array}$ & $\begin{array}{l}\text { Factors measure the impact of a } \\
\text { company's strategy }\end{array}$ & $\begin{array}{l}\text { Sales growth } \\
\text { Customer growth } \\
\text { Sales volume } \\
\text { Market share portion }\end{array}$ & (Lorenzon et al., 2018) [4] \\
\hline
\end{tabular}

Source: (Jogaratnam, 2017) [7], (Essel et al., 2019) [9], (Lorenzon et al., 2018) [4]

\section{Metode Analisis Data}

The data analysis method used is linear regression through the SPSS 16 (Statistical Product and Service Solution) program, namely:

1. Test the effect of $\mathrm{X} 1, \mathrm{X} 2$ on $\mathrm{Z}$. The multiple regression equation is as follows:

$\mathrm{Z}=\mathrm{a}+\beta 1 \mathrm{X} 1+\beta 2 \mathrm{X} 2+\alpha 1$

2. Test the effect of $\mathrm{X} 1, \mathrm{X} 2, \mathrm{Z}$ on $\mathrm{Y}$. The Multiple Regression Equation is as follows:

$$
\mathrm{Y}=\mathrm{b}+\beta 1 \mathrm{X} 1+\beta 2 \mathrm{X} 2+\beta 3 \mathrm{Z1}+\alpha 2
$$

Where,

$\mathrm{a}, \mathrm{b}$ is a multiple regression constant $\beta 1, \beta 2, \beta 3$, are regression coefficients $\mathrm{X} 1$ is Market Orientation
$\mathrm{X} 2$ is an entrepreneurial orientation

$\mathrm{Z}$ is competitive advantage

$\mathrm{Y}$ is marketing performance

\section{RESULT}

The results of data processing with SPSS 16 regression analysis found the results as shown in Table 2 and 3 below:

From Table-1 we can model the multiple linear regression equation as follows:

Table-2

\begin{tabular}{|l|l|l|l|l|}
\hline Independent variable & Regression Coefficient & t count & Probability & (Sig. t) \\
\hline Market orientation (X1) & 0.817 & 6.246 & 0.000 & \\
\hline Enprepreneural orientation (X2) & 0.407 & 3.704 & 0.008 & \\
\hline Konstanta & 10.888 & & & \\
\hline Fcount & 50.975 & & & \\
\hline $\mathrm{R}^{2}$ & 0.659 & & & \\
\hline Adjusment R & & & \\
\hline $\mathrm{R}$ & 0.647 & & \\
\hline Dependent variable: Competitive advantage & & \\
\hline
\end{tabular}

$$
\mathrm{Z}=11.888+0,707 \mathrm{X} 1+0,307 \mathrm{X} 2+\mathrm{e} \mathbf{1}
$$

- First, found constant (a) of 10,8788, this shows the value of the variable competitive advantage if the independent variable is market orientation, entrepreneurial orientation is considered zero.
- Second, the results of data processing found a regression coefficient of market orientation variables $(\beta 1)$ shows that positively has an effect of 0.817 on competitive advantage, this shows a direct effect.

- Third, it is found that the regression coefficient of the entrepreneurial orientation variable $(\beta 2)$ 
shows that positively has an influence of 0.407 on competitive advantage, this shows a direct effect.

- Fourth, we find that the magnitude of the coefficient of determination $\left(\mathrm{R}^{2}\right)=0.659$ with an adjusted $\mathrm{R}$ square of 0.848 , the results explain for market orientation variables, entrepreneurial orientation contributes $65.9 \%$ while the remaining $34.1 \%$ is a contribution to other variables not observed in this model.
- Fifth, we find the magnitude of the multiple correlation coefficient $\mathrm{R}$ (multiplecorelation) explains the strong relationship between independent variables, namely market orientation variables, entrepreneurial orientation together with the dependent variable, namely competitive advantage $(\mathrm{Z})$ of 0.784 . This means that the overall effect of the variable is very close because it is close to 1 for the $\mathrm{R}$ value.

Table-3

\begin{tabular}{|l|l|l|l|}
\hline Independent variable & Regression Coefficient & t count & Probability \\
\hline Market orientation (X1) & 0.707 & 5.246 & 0.000 \\
\hline Enprepreneural orientation (X2) & 0.517 & 2.704 & 0.008 \\
\hline Competitive advantage ( Z ) & 0.545 & 5.646 & 0.000 \\
\hline Konstanta & 6.682 & & \\
\hline Fhitung & 58.975 & & \\
\hline $\mathrm{R}^{2}$ & 0.719 & & \\
\hline Adjusment $\mathrm{R}^{2}$ & 0.728 & \\
\hline $\mathrm{R}$ & 0.848 & \\
\hline Dependent variable: Kinerja Pemasaran & \\
\hline \multicolumn{2}{|l|}{ Source: Primary data processed, March 2019 } \\
\hline
\end{tabular}

From Table-3 we can model the multiple linear regression equation as follows:

$$
\mathrm{Y}=6.682+0.607 \mathrm{X} 1+0.417 \mathrm{X} 2+0.545 \mathrm{Z}+\mathrm{e} 2
$$

- First, we find that the constant (a) of 6.682 indicates the value of the Marketing Performance variable if the independent variable is the market orientation, entrepreneurial orientation, competitive advantage is considered zero.

- Second, we find that the regression coefficient of the market orientation variable $(\beta 1)$ shows that positively has an effect of 0.707 on Marketing Performance, this shows a direct effect.

- Third, we find the regression coefficient of entrepreneurial orientation variables ( $\beta 2)$ shows that negatively has an influence of 0.517 on Marketing Performance, this shows the effect of different directions.

- Fourth, we find that the regression coefficient of the competitive advantage variable $(\beta 3)$ shows that positively has an influence of 0.545 on Marketing Performance, this shows a direct effect.

- Fifth, we find that the coefficient of determination $(\mathrm{R} 2)=0.717$ with an adjusted $\mathrm{R}$ square of 0.728 , these results indicate that the variables Market orientation, Entrepreneurial orientation, Competitive advantage contributed $72.8 \%$ to Marketing Performance, the remaining $27.2 \%$ is the contribution of other variables that are not observed.

- Sixth, we find the magnitude of the multiple correlation coefficient $\mathrm{R}$ (multiplecorelation) explains the strong influence of the independent variable on the dependent variable of 0.848 . This means that there is a very close relationship because the value of $\mathrm{R}$ approaches 1 .

The next step is to test the multiple regression model with the F test. The results of the hypothesis test that we did in full can be presented in Table 4 and 5 .

Table-4: ANOVA ${ }^{b}$

\begin{tabular}{|l|l|l|l|l|l|}
\hline \multicolumn{2}{|l|}{ Model } & Sum of Squares & df & Mean Square & F \\
\hline \multirow{3}{*}{1} & Regression & 1577.200 & 3 & 478.800 & 85.594 \\
\cline { 2 - 6 } & Residual & 641.392 & 116 & 5.529 & \\
\cline { 2 - 6 } & Total & 2077.792 & 119 & & \\
\hline
\end{tabular}

Source: Primary data processed, March 2019

From Table-4, results were found to be 85,594 ; a significant level of 0,000 , as well as df 2 and $\mathrm{df}$ numerator 116. To test the first model which states market orientation, entrepreneurial orientation significantly influences competitive advantage by testing the $\mathrm{F}$ test. $\mathrm{F}$ test results by comparing the $\mathrm{F}$ count with a table at $5 \%$ significance level. From the data processing, we can find that $\mathrm{F}$ calculated with a significant level of 0.000 , with these results it can be said that the proposed hypothesis is proven to be 
accepted stating that market orientation, entrepreneurial orientation has a significant positive effect on competitive advantage. Thus the multiple regression equation model can be continued. Next we present Table 5 about the hypothesis testing of the second multiple regression equation model.

Table-5: ANOVA ${ }^{\mathrm{b}}$

\begin{tabular}{|l|l|l|l|l|l|l|}
\hline \multicolumn{2}{|l|}{ Model } & Sum of Squares & df & Mean Square & F & Sig. \\
\hline \multirow{2}{*}{1} & Regression & 132.345 & 3 & 869.202 & 49.975 & $.000^{\mathrm{a}}$ \\
\cline { 2 - 7 } & Residual & 2058.761 & 116 & 17.748 & & \\
\cline { 2 - 7 } & Total & 3243.544 & 119 & & & \\
\hline
\end{tabular}

Source: Primary data processed, March 2019

From Table-5, we found 49,975 with a significant level of 0,000 , and df 3 and df numerator of 116. To test the second hypothesis which states market orientation, entrepreneurial orientation, competitive advantage has a significant positive effect on marketing performance. The test results were carried out by comparing the $\mathrm{F}$ count with the table at $5 \%$ significance level. From the data processing, we can find that $\mathrm{F}$ calculated with a significant level of 0.000 , with these results it can be said that the proposed hypothesis is proven to be accepted which states that market orientation, entrepreneurial orientation, competitive advantage significantly influence marketing performance.

From equation 1 and 2 models, we then do the hypothesis testing and the results we found for each variable using the partial t-test are seen in Table 5 and 6.

Table-5: Coefficients ${ }^{\mathrm{a}}$

\begin{tabular}{|c|c|c|c|c|c|c|}
\hline \multirow{2}{*}{\multicolumn{2}{|c|}{ Model }} & \multicolumn{2}{|c|}{ Unstandardized Coefficients } & \multirow{2}{*}{$\begin{array}{l}\text { Standardized Coefficients } \\
\text { Beta }\end{array}$} & \multirow[t]{2}{*}{$\mathbf{t}$} & \multirow[t]{2}{*}{ Sig. } \\
\hline & & B & Std. Error & & & \\
\hline \multirow[t]{3}{*}{1} & (Constant) & .609 & 1.342 & & .454 & .651 \\
\hline & Market orient & .099 & .264 & .084 & 2.476 & .003 \\
\hline & Entrepreneural o & .357 & .071 & .340 & 5.042 & .000 \\
\hline \multicolumn{5}{|c|}{ a. Dependent Variable: Competitive Advantage } & & \\
\hline
\end{tabular}

Source: Primary data processed, March 2019

To partially test the influence between variables we use the $\mathrm{t}$ test as follows:

First: Market orientation has a significant positive effect on competitive advantage. The results of the regression analysis obtained the value of $\mathrm{t}$ count $=$ 2.476 while at $\alpha=0.05$ with probability 0.003 less than 0.05 so it is evident that partially the market orientation variable has a significant positive effect on competitive advantage.
Second, entrepreneurial orientation has a significant effect on competitive advantage. We found the results of the regression analysis obtained the value of $\mathrm{t}$ arithmetic $=5.042$ while at $\alpha=0.05$ with a probability of 0.000 less than 0.05 so it is evident that the entrepreneurial orientation variable partially significantly influences competitive advantage. Thus the second hypothesis can be accepted.

Next we present Table- 6 , the results of testing the hypotheses of each variable we find as follows.

Table-6: Coefficients ${ }^{\mathrm{a}}$

\begin{tabular}{|c|c|c|c|c|c|c|}
\hline \multirow{2}{*}{\multicolumn{2}{|c|}{ Model }} & \multicolumn{2}{|c|}{ Unstandardized Coefficients } & \multirow{2}{*}{$\begin{array}{l}\text { Standardized Coefficients } \\
\text { Beta } \\
\end{array}$} & \multirow[t]{2}{*}{$\mathbf{t}$} & \multirow[t]{2}{*}{ Sig. } \\
\hline & & B & Std. Error & & & \\
\hline \multirow[t]{4}{*}{1} & (Constant) & 4.082 & 2.093 & & 1.950 & .054 \\
\hline & Market orientation & .607 & .074 & .577 & 5.246 & .000 \\
\hline & Entrepreneural orientation & .207 & .077 & -.192 & 2.704 & .008 \\
\hline & Competitive advantage & .454 & .080 & .400 & 5.646 & .000 \\
\hline \multicolumn{3}{|c|}{ a. Dependent Variable: Marketing P } & & & & \\
\hline
\end{tabular}

Source: Primary data processed, March 2019

Third, market orientation has a significant effect on marketing performance. We found the results of the regression analysis obtained the value of $t$ arithmetic $=5.246$ while at $\alpha=0.05$ with a probability of 0.000 less than 0.05 so it is evident that partially market orientation variables significantly influence marketing performance. 
Fourth, entrepreneurial orientation has a significant effect on marketing performance. We found the results of the regression analysis obtained the value of $\mathrm{t}$ arithmetic $=2.704$ while at $\alpha=0.05$ with a probability 0.008 less than 0.05 so it is evident that partially the entrepreneurial orientation variable has a significantly positive effect on marketing performance.

Fifth, competitive advantage has a significant positive effect on marketing performance. We found the results of the regression analysis obtained the value of $t$ arithmetic $=5.646$ while at $\alpha=0.05$ with a probability of 0,000 less than 0.05 so that it is evident that partially the variable has a positive and significant effect.

\section{DISCUSSION}

The first hypothesis was found to have a significant positive effect between market orientation on competitive advantage. Thus the first hypothesis can be accepted. This is in line with studies $[7,16]$ which find that market orientation has a significant positive effect on competitive advantage. It means that three indicators namely customer orientation, competitor and inter-functional coordination have been proven to have an effect on product excellence as indicated by indicators of product uniqueness, competitive prices, rarely found and irreplaceable, contributing to the sustainability of the company. This means that the company has advantages in terms of customer knowledge and these advantages can be used as a source for creating products that match the wants and needs of customers. These results support [4] that organizational culture emphasizes the importance of markets for strengthening competitive advantage.

The second hypothesis was found to have a significant positive effect between entrepreneurial orientation on competitive advantage. So the second hypothesis is accepted. This supports research [9, 16, 4]. This means that entrepreneurial orientation has a significant positive effect on competitive advantage. This research was measured by five indicators namely flexible, proactive, courage to take risks, business experience, and anticipatory. Taking risk means someone is oriented towards opportunities in conditions of uncertainty. Flexibility is that it can change according to customer wishes. Proactive is a leader who has the ability to recognize opportunities and commitments in innovation. Business experience means that the attitude of the entrepreneur in his behavior is influenced by the background of his leadership. Anticipatory is the ability to cope or anticipate all changes.

The third hypothesis was found to have a significant positive effect on market orientation on marketing performance. Thus hypothesis 3 can be accepted. This is in line with [18]. Jogaratnam [7], found that market orientation has a significant positive effect on marketing performance. This means that marketing performance is measured by indicators of sales growth; Customer growth; Sales volume; Market share portion. This means that companies applying market orientation will provide better services so they can satisfy their customers to get higher business profits.

Fourth, entrepreneurial orientation has a significant positive effect on marketing performance. So the fourth hypothesis can be accepted. This supports [9, 16]. Rachinger et al., [5], found entrepreneurial orientation had a significant positive effect on marketing performance. This means that entrepreneurial orientation is proven to have a significant positive effect on marketing performance. The higher the company's ability to market its products, the better business performance.

Fifth, competitive advantage has a significant positive effect on marketing performance. So hypothesis 5 can be accepted. This research is in line with [4] who found that competitive advantage had a positive and significant effect on marketing performance. This means that product uniqueness, competitive prices, rarely found and irreplaceable contribute to the sustainability of the company proven to have a significant influence on marketing performance. Companies that are able to create competitive advantage have the strength to compete with other companies. Thus competitive advantage has a significant positive influence on improving marketing performance.

\section{CONCLUSION}

Based on the results of the study can be concluded as follows:

1. That market orientation has a significant positive effect on competitive advantage.

2. Entrepreneurial orientation has a significant positive effect on competitive advantage.

3. Market orientation has a significant positive effect on marketing performance

4. Entrepreneurial orientation has a significant positive effect on marketing performance.

5. Competitive advantage has a significant positive effect on marketing performance

\section{Research Implications}

The findings of this study are that market orientation, entrepreneurial orientation, contribute significantly to competitive advantage and market orientation, entrepreneurial orientation, competitive advantage contribute significantly to marketing performance. Therefore the managerial implications in managing SMEs in the city of Semarang are as follows.

The first, Customer orientation is oriented to customer satisfaction, by observing customer behavior, showing responsively creating superior value. While the competitor's orientation continually follows the 
development of competitors, by understanding the short-term strengths, weaknesses, abilities, and longterm strategies of competitors.

The second, being proactive can be achieved by encouraging employees to want to care about changes that occur, not being resigned to the circumstances and the willingness to look for various market opportunities for products and ahead of competitors in introducing their products. The courage to take risks can be done by expanding by opening new companies elsewhere, developing new products, and entering new markets.

The third, Companies must always evaluate the price of the product with the price of competitors, so that the price set is not much different from competitors. So as to be able to enter the market, to maintain the quality of raw materials and product specificity.

Fourth, Increase sales through training salespeople, fostering good relations with customers, minimizing defective products, tightening quality control, expanding the reach of the region as well as seeing opportunities for marketing their products.

\section{RESEARCH LIMITATIONS}

This study has limitations

The first, hypothesis testing results only see the contribution of market orientation, entrepreneurship to competitive advantage. It is recommended to do replication research with an expansionary design so that its contribution will be more accurate.

The second, limitations of this study also only see the magnitude of the contribution of the variables used. Future studies are expected to examine other variables that can increase sales.

\section{REFERENCES}

1. Medlin, C. J., \& Ellegaard, C. (2015). Conceptualizing competition and rivalry in a networking business market. Industrial Marketing Management, 51(2015), 131-140.

2. Duffett, R. G. (2017). Influence of social media marketing communications on young consumers' attitudes. Young Consumers, 18(2017), 19-39.

3. Parida, V., \& Wincent, J. (2019). Why and how to compete through sustainability: a review and outline of trends influencing firm and networklevel transformation. International Entrepreneurship and Management Journal, 1-19.

4. Lorenzon, J. R. F., Rubio, M. T. M., \& Garcés, S. A. (2018). The competitive advantage in business, capabilities and strategy. What general performance factors are found in the Spanish wine industry? Wine Economics and Policy, 7(2018), 94-108.
5. Rachinger, M., Rauter, R., Müller, C., Vorraber, W., \& Schirgi, E. (2019). Digitalization and its influence on business model innovation. Journal of Manufacturing Technology Management, 30(8):1143-1160.

6. Sofana, A., Rosyidi, C. N., \& Pujiyanto, E. (2019). Product quality improvement model considering quality investment in rework policies and supply chain proft sharing. Journal of Industrial Engineering International, 15(2019), 637-649

7. Jogaratnam, G. (2017). How organizational culture influences market orientation and business performance in the restaurant industry. Journal of Hospitality and Tourism Management, 31(2017):211-219.

8. Jyoti, J., \& Sharma, J. (2012). Impact of Market Orientation on Business Performance: Role of Employee Satisfaction and Customer Satisfaction. Impact of Market Orientation on Business Performance, 16 (4), 297-313.

9. Essel, B. K. C., Adams, F., \& Amankwah, K. (2019). Effect of entrepreneur, firm, and institutional characteristics on small-scale firm performance in Ghana. Journal of Global Entrepreneurship Research, 9(5), 1-20.

10. Zhu, C., Liu, A., \& Wang, Y. (2019). Integrating organizational learning with high-performance work system and entrepreneurial orientation: a moderated mediation framework. Frontiers of Business Research in China, 13(11), 1-24.

11. Arief, M., Thoyib, A., Sudiro, A., \& Rohman, F. (2013). The Effect of Entrepreneurial Orientation on the Firm Performance through Strategic Flexibility: A Study on the SMEs Cluster in Malang Journal of Management Research, 5(3).

12. Li, Y. H., Huang, J. W., \& Tsai, M. T. (2008). Entrepreneurial orientation and firm performance: The role of knowledge creation process. Industrial Marketing Management.

13. Zainol, D. F. A., \& Ayadurai, D. S. (2011). Entrepreneurial Orientation and Firm Performance: The Role of Personality Traits in Malay Family Firms in Malaysia International Journal of Business and Social Science, 2(1).

14. Rezaei, J., \& Ortt, R. (2018). Entrepreneurial orientation and firm performance: the mediating role of functional performances. Management Research Review, 41(7), 878-900.

15. Ranta, V., Keränen, J., \& Aarikka-Stenroos, L. (2019). How B2B suppliers articulate customer value propositions in the circular economy: Four innovation-driven value creation logics. Industrial Marketing Management, 1-15.

16. Na, Y. K., Kang, S., \& Jeong, H. Y. (2019). The Effect of Market Orientation on Performance of Sharing Economy Business: Focusing on Marketing Innovation and Sustainable Competitive Advantage. Sustainability, 11(729), $1-19$. 
17. Hoa, K. K. L. P., Nguyenb, C. N., Rajendra Adhikari a, M. P. M. c., \& Hoa, L. B. L. P. (2018). Exploring market orientation, innovation, and financial performance in agricultural value chains in emerging economies. Journal of Innovation \& Knowledge, 3(2018), 154-163.

18. Rehme, S., \& Rennhak, C. (2012). The conflict between marketing and sales. Innovative Marketing, 8(2).

19. Koh, E. T., Torabinejad, M., Pitt Ford, T. R., Brady, K., \& McDonald, F. (1997). Mineral trioxide aggregate stimulates a biological response in human osteoblasts. Journal of Biomedical Materials Research: An Official Journal of The Society for Biomaterials and The Japanese Society for Biomaterials, 37(3), 432-439.

20. Dziallasa, M., \& Blind, K. (2019). Innovation indicators throughout the innovation process: An extensive literature analysis. Technovation, 8081(2019), 3-29.

21. Sugiyarti, G., \& Ardyan, E. (2017). Market Sensing Capability and Product Innovation Advantages in Emerging Markets: The Case of Market Entry Quality and Marketing Performance of Batik Industry in Indonesia. DLSU Business \& Economics Review, 27(1), 1-12.

22. Snyder, H. (2019). Literature review as a research methodology: An overview and guidelines. Journal of Business Research, 104(2019), 333339.

23. Palinkas, L. A., Horwitz, S. M., Green, C. A., Wisdom, J. P., Duan, N., \& Kimberly, H. (2015). Purposeful sampling for qualitative data collection and analysis in mixed method implementation research. Adm Policy Ment Health, 42(5), 533-544. 